\title{
Chromosomal and Banding Studies in Sphaerium indicum (Bivalvia: Mollusca)
}

\author{
Poonam $^{1 *}$, N.K. Tripathi ${ }^{1}$ and Preetpal Kour ${ }^{2}$ \\ ${ }^{1}$ Department of Zoology, Central University of Jammu, Rahya-Suchani (Bagla), District \\ Samba-181143, Jammu, India \\ ${ }^{2}$ Department of Zoology, GCW Parade, Jammu, India \\ *Corresponding author
}

\section{A B S T R A C T}

\begin{tabular}{|l|}
\hline Ke y w or d s \\
$\begin{array}{l}\text { Sphaerium, Veneroida, } \\
\text { Chromosome, Mitosis }\end{array}$ \\
\hline Article Info \\
\hline $\begin{array}{l}\text { Accepted: } \\
\text { 24 August } 2018 \\
\text { Available Online: } \\
\text { 10 September } 2018\end{array}$ \\
\hline
\end{tabular}

During the present study, mitotic chromosomes of freshwater snail Sphaerium indicum were studied using gills. The observed diploid chromosome number was $2 n=30$ consisting of 26 metacentric pairs and 04 submetacentric pairs respectively. Chromosomes were studied using Giemsa staining and two banding techniques viz. C-banding and Ag-NOR banding. Preliminary $\mathrm{C}$-band studies revealed the presence of terminal blocks besides the presence of centromeric heterochromatin. The nucleolar organizer region (NOR) was found on one chromosome pair i.e. on the submetacentric chromosome pair no. 5. The cytogenetic relationship between $S$. indicum and other species of Veneroida was also discussed.

\section{Introduction}

Molluscs are abundant, varied and widespread. This and the diversity of their karyotypes make them particularly suited to cytogenetic research. Cytogenetics studies encompass different levels of biological organization ranging from the morphological to the molecular, depending on the applicable technology. Chromosomes can be studied as a morphological manifestation of the genome in terms of their microscopically visible size, shape, number and behavior during meiosis and mitosis. At another level, banding studies reveal finer details of chromosomal morphology. Studies of natural or induced deviation from the diploid chromosome number also contribute significant cytogenetic data. Among bivalves, the first investigation concerned the chromosome number (Patterson, 1969). Then, pre-treatment with colchicine and hypotonic treatment, combined with the air drying technique, permitted accurate assessments of chromosome morphology (Nakamura, 1985). Later, the development of banding techniques which allowed chromosome identification in karyotypes began to be applied in bivalves (Thiriot-Quievreux, 1994).

$S$. indicum is an abundant mollusc species in the Himalayan streams and riverlets within the 
elevation range of $800-1600 \mathrm{~m}$. The preferred habitat is sandy gravel or muddy substrate closed to the banks and slow running water bodies. It belongs to Phylum -Mollusca, Class-Bivalvia, Order- Veneroida, Family Pisiidae and Genus - Sphaerium species indicum.

Taxonomic characters includes: Shell in equilateral, right valve with a single well developed cardinal, Mantle very thin and without any papillae on the edge. It is commonly known as Fingernail Clam.

\section{Materials and Methods}

The snails were collected from slow running fresh water streams. Snails were taken alive to the laboratory, then maintained in tanks of aerated water and fed continuously to promote growth. Chromosome preparations were obtained from the gills tissue.

After taxonomic verification of each snail, were floated for $24 \mathrm{hrs}$ in $0.1 \%$ colchicine. Snails were dissected and their gills removed and treated with $0.07 \% \mathrm{KCl}$ as hypotonic solution, at room temperature for $30 \mathrm{~min}$. The tissues after hypotonic treatment were fixed in Carnoy's fixative. The slides were stained with $4 \%$ Giemsa buffer solution for $30 \mathrm{~min}$. scanning and photomicrography of the slides was done using Nikon YS100 binocular research microscope and Samsung SDC-313 camera respectively. Well spread suitable mitotic stages were photomicrographed at a magnification of $1000 \mathrm{x}$. The morphological classification of chromosomes proposed by Levan et al., (1964) has been followed to categorize the chromosomes as metacentrics, submetacentrics, subtelocentrics or telocentric. The chromosomes were classified into uniarmed and biarmed following Chen and Ebelling (1971) to calculate the fundamental arm number (FN). Idiogram and Histogram was prepared.

\section{Observations}

A total of 40-50 metaphase stages were selected to establish the diploid chromosome number. The basic chromosome number was found to be $2 n=30$ (Fig. 1). All chromosomes in the karyotypes were biarmed and of two types, that is, metacentric and submetacentric type (Fig. 2) Haploid formula for the complement was calculated as $n=13 M+2 S M$ and the corresponding fundamental arm number was calculated as NF=60 (Table 1).

The mean total haploid length and total diploid length was $12.73 \mu$ mand25.46 $\mu \mathrm{m}$ respectively. Histogram and Idiogram was also prepared (Fig. 3 and 4) In C- Banding, Chromosome pair numbers 1, 2, 3, 4, 5, 6, 10, 11 and 15 showed telomeric C-bands, while the chromosome pair number $7,8,9,12,13$ and 14 showed centromeric C-bands (Fig. 5 and 6) while in NOR- Banding, one pair of darkly stained NOR was observed in a short arm of submetacentric chromosome pair $\left(5^{\text {th }}\right.$ pair) (Fig. 7 and 8).

\section{Results and Discussion}

Although Bivalves are an important component of the marine and freshwater fauna, their chromosomal studies have received a little consideration than they actually deserve. Karyotypic details have been documented in several animal groups including a few Bivalvia species (Cornet and Soulard, 1990; Wada and Komaru, 1993; Insua et al., 1998; Martinez-Lage et al., 2002; Lopez-Pinon et al., 2005; Insua et al., 2006). Karyotypes with a majority of metacentricsubmetacentric chromosomes are also characteristic of most bivalve species (ThiriotQuievreux, 2002), but this feature is not a general rule among invertebrates (White, 1973). Out of 10,000 described species of Bivalvia only 139 species has been studied cytogenetically till date. 
Fig.1 Metaphase complement from gill

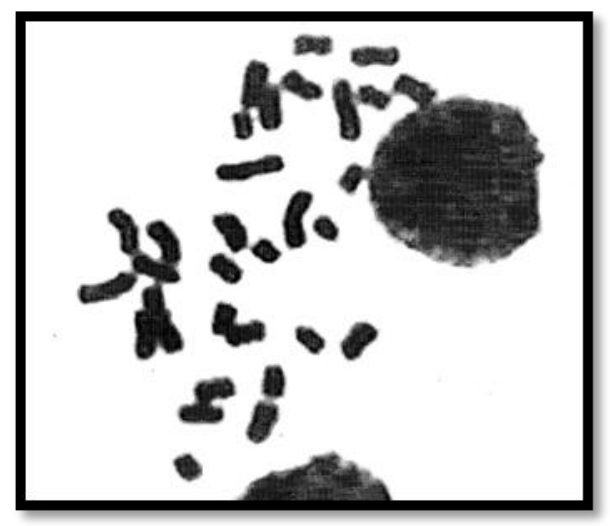

Fig.3 Histogram

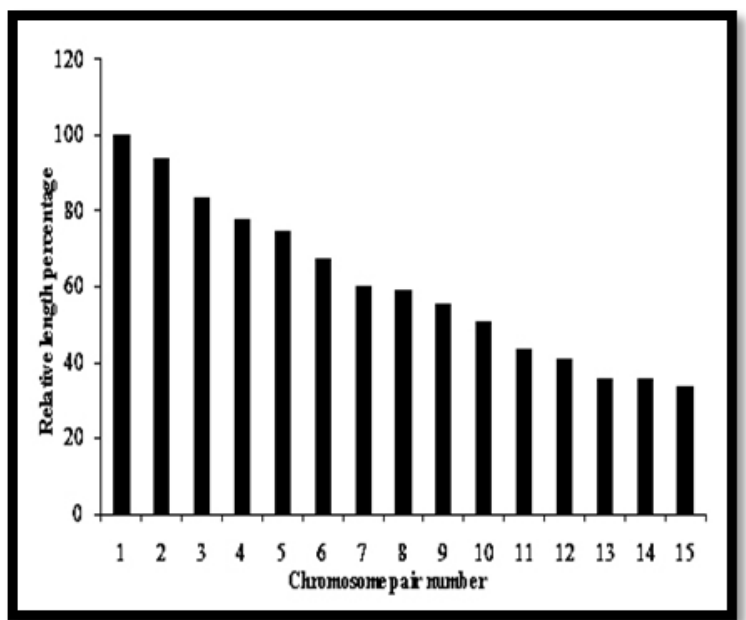

Fig. 2 karyotype showing $2 \mathrm{n}=30(26 \mathrm{~m}+4 \mathrm{sm})$

Tissue of $S$. indicum $(2 \mathrm{n}=30)$

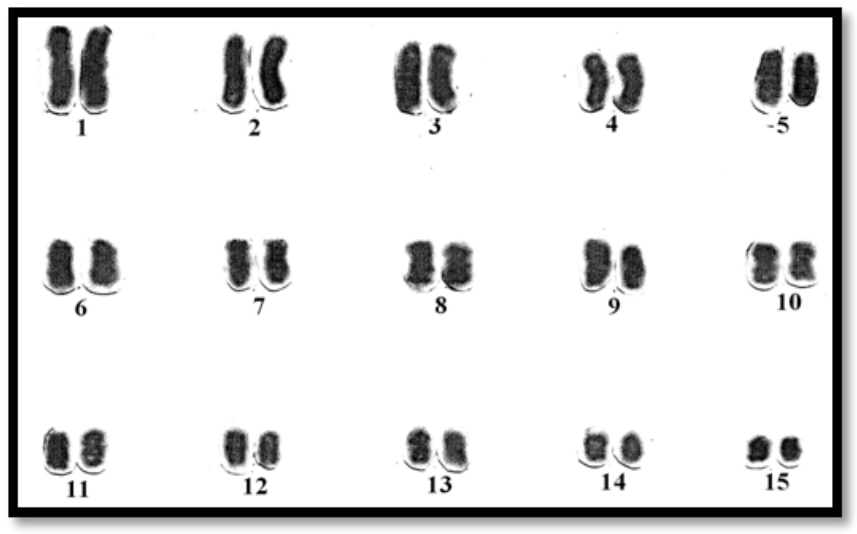

Fig.4 Idiogram

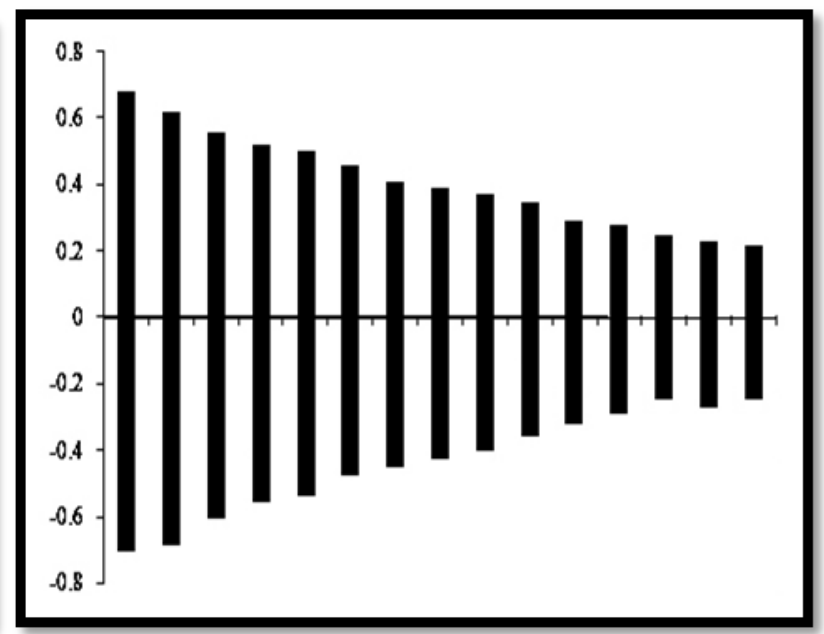

Fig.5 C-banded metaphase complement Fig.6 Karyotype of C-banded metaphase complement

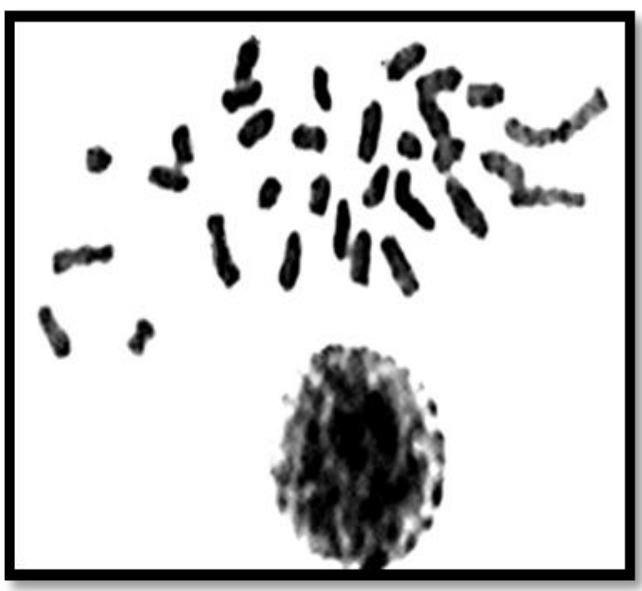

\begin{tabular}{|c|c|c|c|c|}
\hline$\varepsilon_{1}^{5}$ & $\frac{8}{2}$ & & 8 & $8_{5}$ \\
\hline$\prod_{6}$ & 1) & 8 & 8) & 88 \\
\hline 79 & $\underset{12}{6}$ & ${ }_{13}^{8}$ & 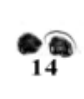 & 15 \\
\hline
\end{tabular}


Fig.7 NOR banded metaphase complement
Fig.8 Karyotype of NOR-banded metaphase Complement
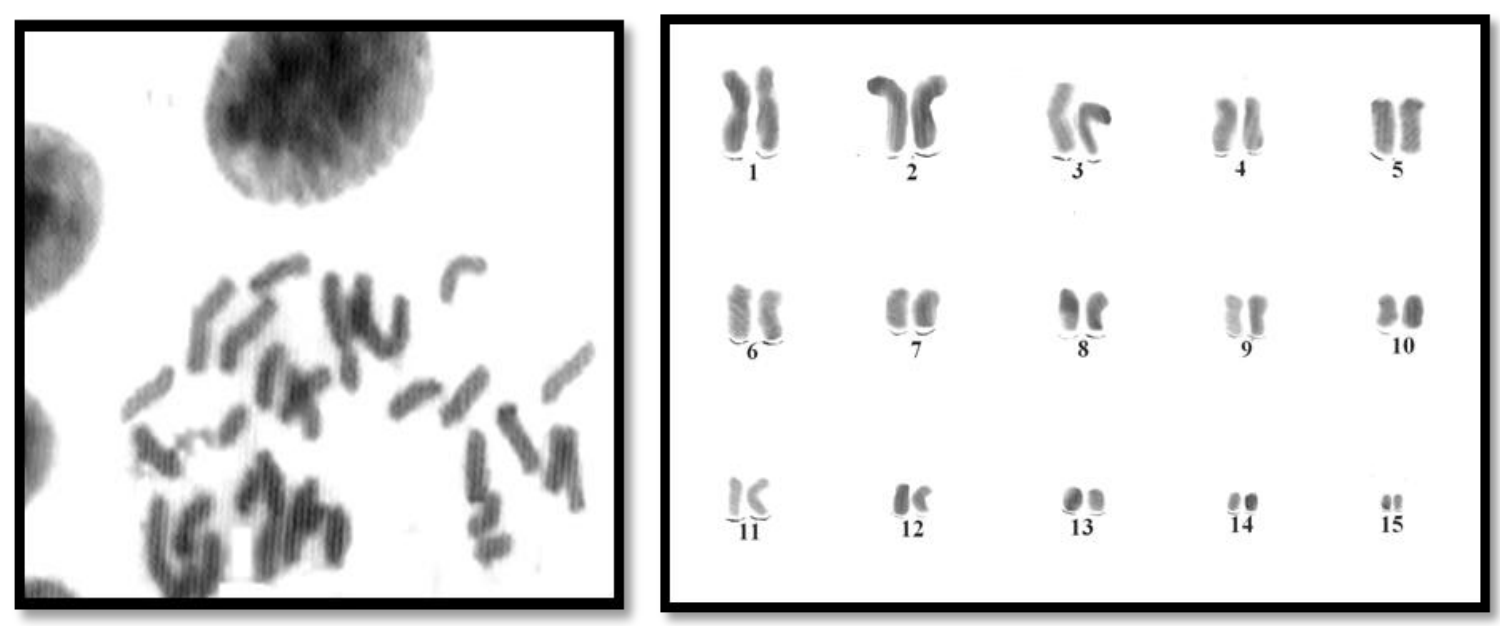

Table.1 Morphometric data of karyotype of $S$. indicum showing $2 n=30(26 m+4 s m)$

\begin{tabular}{|c|c|c|c|c|c|c|c|c|}
\hline $\begin{array}{l}\text { Chromoso } \\
\text { me pair no. }\end{array}$ & $\begin{array}{l}\text { Mean } \\
\text { length } \\
\text { of the } \\
\text { short } \\
\text { arm (p) } \\
\text { in } \mu \mathrm{m}\end{array}$ & $\begin{array}{l}\text { Mean } \\
\text { length of } \\
\text { the long } \\
\text { arm (q) } \\
\text { in } \mu \mathrm{m}\end{array}$ & $\begin{array}{c}\text { Absolute } \\
\text { length } \\
(p+q) \text { of } \\
\text { the } \\
\text { chromoso } \\
\text { me in } \mu \mathrm{m}\end{array}$ & $\begin{array}{l}\text { Arm } \\
\text { ratio } \\
(q / p)\end{array}$ & $\begin{array}{c}\text { Relative } \\
\text { length } \\
\text { percentage }\end{array}$ & $\begin{array}{c}\text { Total } \\
\text { complement } \\
\text { length } \\
\text { percentage }\end{array}$ & $\begin{array}{l}\text { Centromeric } \\
\text { index }\end{array}$ & Nomenclature \\
\hline 1 & 0.68 & 0.71 & 1.39 & 1.04 & 100.00 & 5.46 & 48.92 & Metacentric \\
\hline 2 & 0.62 & 0.69 & 1.31 & 1.11 & 94.24 & 5.15 & 47.32 & Metacentric \\
\hline 3 & 0.56 & 0.60 & 1.16 & 1.07 & 83.45 & 4.56 & 48.27 & Metacentric \\
\hline 4 & 0.52 & 0.56 & 1.08 & 1.07 & 77.69 & 4.24 & 48.14 & Metacentric \\
\hline 5 & 0.50 & 0.54 & 1.04 & 1.08 & 74.82 & 4.08 & 48.07 & Submetacentric \\
\hline 6 & 0.46 & 0.48 & 0.94 & 1.04 & 67.62 & 3.69 & 48.93 & Metacentric \\
\hline 7 & 0.41 & 0.45 & 0.86 & 1.09 & 60.43 & 3.38 & 47.67 & Metacentric \\
\hline 8 & 0.39 & 0.43 & 0.82 & 1.10 & 58.99 & 3.22 & 47.56 & Submetacentric \\
\hline 9 & 0.37 & 0.40 & 0.77 & 1.08 & 55.39 & 3.02 & 48.05 & Metacentric \\
\hline 10 & 0.35 & 0.36 & 0.71 & 1.02 & 51.07 & 2.79 & 49.29 & Metacentric \\
\hline 11 & 0.29 & 0.32 & 0.61 & 1.10 & 43.88 & 2.39 & 47.54 & Metacentric \\
\hline 12 & 0.28 & 0.29 & 0.57 & 1.03 & 41.00 & 2.24 & 49.12 & Metacentric \\
\hline 13 & 0.25 & 0.25 & 0.50 & 1.25 & 35.97 & 1.96 & 50.00 & Metacentric \\
\hline 14 & 0.23 & 0.27 & 0.50 & 1.17 & 35.97 & 1.96 & 46.00 & Metacentric \\
\hline 15 & 0.22 & 0.25 & 0.47 & 1.13 & 33.81 & 1.85 & 46.80 & Metacentric \\
\hline
\end{tabular}

The diploid chromosome number ranges between 12-62, with 28 being the most common (28.8\%); followed by $38(25.2 \%)$ and $20(17.3 \%)$. Cytogenetic studies conducted on bivalves have revealed significant variation in the number of 
chromosomes. In a review (Nakamura, 1985), it was reported that the order Veneroida, has diploid chromosome number from 24 to 48 and the most common chromosome number was $2 n=38$. However, deviations from this pattern appeared within individual families.

In family Pisidiidae (Bivalvia: Veneroida), three species has been studied cytologically till date, viz. Sphaerium corneum, $2 \mathrm{n}=30$ with $26 \mathrm{~m}+4 \mathrm{sm} \quad$ chromosomes $\quad(\mathrm{FN}=60)$ (Petkeviciute et al., 2006; Korinkova and Kral, 2011); S. nucleus, $2 \mathrm{n}=30$ with $28 \mathrm{~m}+2 \mathrm{sm}$ chromosomes $(\mathrm{FN}=60)$ (Korinkova and Kral, 2011) and $S$. nitidum, $2 \mathrm{n}=44$ with $24 \mathrm{~m}+8 \mathrm{sm}$ +12 st chromosomes $(\mathrm{FN}=88)$ (Barsiene and Barsyte, 2000). In present study for the first time, chromosomal and banding studies of $S$. indicum has been done. The diploid complement of $2 n=30$ with $26 m+4 s m$ chromosomes $(\mathrm{FN}=60)$ was observed in $S$. indicum, showing the presence of only biarmed chromosomes. This may be due to Robertsonian translocation (centric fission) of chromosomes or polyploidy as there was almost doubling in the chromosome as compared to other species.

\section{References}

Barsiene, J. and Barsyte, D. (2000). Environmental Genotoxicity in Klaipeda Port Area. Int. Rev. Hydrobiol., 85: 663-672.

Chen, T.R. and Ebelling, A.W. Chromosomes of the goby fishes in the genus Gallichthys. Copeia, 1971; 1: 171-174.

Cornet and Soulard, 1990; Cornet, M. and Soulard, C. (1990). Chromosome number and karyotype of Donaxtrun culus L. (Mollusca: Bivalvia: Tellinacea). Genetica, 82(2): 93-97.

Insua et al., 1998; Insua, A., Lopez-Pinon, M.J. and Mendez, J. (1998). Characterization of Aequipecten opercularis (Bivalvia: Pectinidae) chromosomes by different staining techniques and fluorescent in situ hybridization. Genes Genetic System, 73: 193-200. Insua,

Insua et al., 2006 Insua, A., Lopez-Pinon, M.J., Freire, R. and Mendez, J. (2006). Karyotype and chromosomal location of 18S-28S and 5S ribosomal DNA in the scallops Pecten maximus and Mima chlamysvaria (Bivalvia: Pectinidae). Genetica, 126(3): 291- 301.

Korinkova, T. and Kral, J. (2011). Structure and meiotic behaviour of $B$ chromosomes in Sphaerium corneum/S. nucleus complex (Bivalvia: Sphaeriidae). Genetica, 139: 155-165.

Levan, A., Fredga, K. and Sandberg, A.A. Nomenclature for Centromeric position on chromosomes. Hereditas, 1964; 52: 201-220.

Lopez-Pinon et al., 2005; Lopez-Pinon, M.J., Insua, A. and Mendez, J. (2005). Chromosome analysis and mapping of ribosomal genes by one- and two-color fluorescent in situ hybridization in Hinnites distortus (Bivalvia: Pectinidae). J. Hered., 96(1): 52-58.

Martinez-Lage et al., 2002; Martinez-Lage, A., Gonzalez-Tizon, A. and Mendez, J. (2002). Cytogenetic characterization of Donaxtrun culus (Bivalvia: Donacidae) by means of Karyotyping, fluorochrome banding and fluorescent in situ hybridization. J. Moll. Stud., 68: 393396.

Nakamura, H.K. 1985. A review of molluscan cytogenetic information based on CISMOCH-Computerized index system for molluscan chromosomes. Bivalvia, Polyplacophora and Cephalopoda. Venus, Japanese Journal of Malacology, 44:193-225

Patterson, C.M. 1969. Chromosomes of molluscs. In: Proceedings of the $2^{\text {nd }}$ Symposium of Mollusca, Cochin, India, 
Marine Biological Association of India, 2: 635-689.

Petkeviciute, R., Stunzenas, V. and Staneviciute, G. (2006). Polymorphism of the Sphaerium corneum (Bivalvia: Veneroida: Sphaeriidae) revealed by cytogenetic and sequence comparison. Biological Journal of the Linnean Society, 89: 53-64.

Thiriot-Quievreux, C. 1994. Advances in cytogenetics of aquatic organisms. In: Genetics and Evolution of Aquatic Organisms, (A.R. Beaumont ed.), pp. 369-388. Chapman \& Hall.
Thiriot-Quievreux, C. (2002). Review on the literature on bivalve cytogenetics in the last ten years. Cah. Biol. Mar., 43: 1726. Thiriot-

Wada and Komaru, 1993; Wada, K.T. and Komaru, A. (1993). Karyotype of the Chinese Mactra clam, Mactra chinensis (Bivalve: Mactridae). Venus, 52(1): 6368.

White, M.J.D. (1973). Animal Cytology and Evolution. London: Cambridge University Press, pp. 961.

\section{How to cite this article:}

Poonam, N.K. Tripathi and Preetpal Kour. 2018. Chromosomal and Banding Studies in Sphaerium indicum (Bivalvia: Mollusca). Int.J.Curr.Microbiol.App.Sci. 7(09): 3369-3374. doi: https://doi.org/10.20546/ijcmas.2018.709.418 